\title{
Association of hyperchloremia with all-cause mortality in patients admitted to the surgical intensive care unit: a retrospective cohort study
}

Keke Song, Tingting Yang and Wei Gao*

\begin{abstract}
Background: Serum chloride $\left(\mathrm{Cl}^{-}\right)$is one of the most essential extracellular anions. Based on emerging evidence obtained from patients with kidney or heart disease, hypochloremia has been recognized as an independent predictor of mortality. Nevertheless, excessive $\mathrm{Cl}^{-}$can also cause death in severely ill patients. This study aimed to investigate the relationship between hyperchloremia and high mortality rate in patients admitted to the surgical intensive care unit (SICU).

Methods: We enrolled 2131 patients from the Multiparameter Intelligent Monitoring in Intensive Care III database

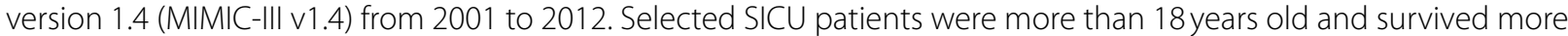
than $72 \mathrm{~h}$. A serum $\mathrm{Cl}^{-}$level $\geq 108 \mathrm{mEq} / \mathrm{L}$ was defined as hyperchloremia. Clinical and laboratory variables were compared between hyperchloremia $(n=664)$ at $72 \mathrm{~h}$ post-ICU admission and no hyperchloremia $(n=1467)$. The Locally Weighted Scatterplot Smoothing (Lowess) approach was utilized to investigate the correlation between serum Cland the thirty-day mortality rate. The Cox proportional-hazards model was employed to investigate whether serum chlorine at $72 \mathrm{~h}$ post-ICU admission was independently related to in-hospital, thirty-day and ninety-day mortality from all causes. Kaplan-Meier curve of thirty-day and ninety-day mortality and serum $\mathrm{Cl}^{-}$at $72 \mathrm{~h}$ post-ICU admission was further constructed. Furthermore, we performed subgroup analyses to investigate the relationship between serum $\mathrm{Cl}^{-}$at $72 \mathrm{~h}$ post-ICU admission and the thirty-day mortality from all causes.

Results: A J-shaped correlation was observed, indicating that hyperchloremia was linked to an elevated risk of thirty-day mortality from all causes. In the multivariate analyses, it was established that hyperchloremia remained a valuable predictor of in-hospital, thirty-day and ninety-day mortality from all causes; with adjusted hazard ratios (95\% Cls) for hyperchloremia of 1.35 (1.02 1.77), 1.67 (1.28 2.19), and 1.39 (1.12 1.73), respectively. In subgroup analysis, we observed hyperchloremia had a significant interaction with AKI (P for interaction: 0.017 ), but there were no interactions with coronary heart disease, hypertension, and diabetes mellitus ( $P$ for interaction: 0.418, 0.157, 0.103, respectively).
\end{abstract}

Conclusion: Hyperchloremia at $72 \mathrm{~h}$ post-ICU admission and increasing serum $\mathrm{Cl}^{-}$were associated with elevated mortality risk from all causes in severely ill SICU patients.

Keywords: Hyperchloremia, All-cause mortality, Surgical intensive care unit

*Correspondence: gaoweixjtu2021@126.com

Department of Anesthesiology, The First Affiliated Hospital of Xi'an

Jiaotong University, No. 277, Yanta West Road, Yanta District, Xi'an, China
Serum chloride $\left(\mathrm{Cl}^{-}\right)$is one of the essential extracellular anions responsible for about a third of plasma tonicity, about $97-98 \%$ of all the strong anionic charges, and two-thirds of negative charges in the plasma $[1,2]$. $\mathrm{Cl}^{-}$plays pivotal roles in numerous body functions, original author(s) and the source, provide a link to the Creative Commons licence, and indicate if changes were made. The images or other third party material in this article are included in the article's Creative Commons licence, unless indicated otherwise in a credit line to the material. If material is not included in the article's Creative Commons licence and your intended use is not permitted by statutory regulation or exceeds the permitted use, you will need to obtain permission directly from the copyright holder. To view a copy of this licence, visit http://creativecommons.org/licenses/by/4.0/. The Creative Commons Public Domain Dedication waiver (http://creativeco mmons.org/publicdomain/zero/1.0/) applies to the data made available in this article, unless otherwise stated in a credit line to the data. 
e.g., maintenance of acid-base balance, maintenance of osmotic pressure, maintenance of muscular activity, and the movement of water between fluid compartments [1]. Despite its physiologic importance, it might still be easier to focus on potassium or sodium and water balance rather than $\mathrm{Cl}^{-}$in clinical settings. Much less research attention has been accorded to $\mathrm{Cl}^{-}$relative to other electrolytes. However, recently, more and more studies have reported the significance of serum $\mathrm{Cl}^{-}$. Emerging research evidence on individuals with heart or kidney disease has shown that hypochloremia served as an independent indicator of mortality [3-7]. However, hyperchloremia is also related to poor clinical outcomes in severely ill patients [8-11].

Nevertheless, to our knowledge, no study has studied the relationship linking hyperchloremia to mortality in the surgical intensive care unit (SICU). To that end, we aimed to establish whether hyperchloremia is linked to a high mortality rate in patients admitted to the SICU.

\section{Materials and methods}

This involved a retrospective cohort study that employed Multiparameter Intelligent Monitoring in Intensive Care III database version 1.4 (MIMIC-III v1.4). From 2001 to 2012, more than 38,000 patients in the Beth Israel Deaconess Medical Center's ICU in Boston, Massachusetts, United States (US) have been included in the MIMIC-III v1.4 [2, 12]. The database is publicly available to researchers who have completed a 'protecting human subjects' training. The Review Board of the Massachusetts Institute of Technology and Beth Israel Deaconess Medical Center approved the establishment of the database. Thus, consent was obtained for the original data collection, but not specifically for this study. Data presented in this study were extracted by the author, Song, who completed the online training course of the National Institutes of Health (certification number: 37814178). The data was extracted using the PostgreSQL tool V.9.6 to obtain the clinical data containing patient demographics, laboratory findings, mortality, and other clinical variables. To maintain the confidentiality of the included study subjects, all sensitive information was hidden.

\section{Population selection criteria}

The MIMIC-III v1.4 comprised of 46,476 patients. Patients were selected according to the following inclusion criteria: 1) first hospitalization; 2) admitted to the SICU; and 3) older than 18. Participants were excluded according to the following criteria: 1) no serum $\mathrm{Cl}^{-}$at $72 \mathrm{~h}$ after ICU admission; 2) missing $>5 \%$ individual data.

\section{Data abstraction}

The demographic factors, laboratory parameters, the scoring system, and the clinical factors were extracted. Only the data of the first SICU admission of each study subject were utilized, and baseline data were abstracted within $24 \mathrm{~h}$ after SICU admission. The comorbidities consisted of coronary heart disease (diagnosed as "coronary atherosclerosis" in the database), chronic obstructive pulmonary disease (COPD, diagnosed as "obstructive chronic bronchitis without exacerbation" or "obstructive chronic bronchitis with (acute) exacerbation" or "obstructive chronic bronchitis with acute bronchitis" in the database), hypertension (diagnosed as "benign essential hypertension" or "unspecified essential hypertension" in the database), diabetes mellitus (diagnosed as "diabetes" in the database), and acute kidney injury (AKI, an increase in serum creatinine level of more than 1.5 times above baseline). Laboratory findings at $72 \mathrm{~h}$ after ICU admission included serum chloride $\left(\mathrm{Cl}_{72 \mathrm{~h}}\right)$, serum sodium $\left(\mathrm{Na}_{72 \mathrm{~h}}\right)$, serum potassium $\left(\mathrm{K}_{72 \mathrm{~h}}\right)$, blood urea nitrogen $\left(\mathrm{BUN}_{72 \mathrm{~h}}\right)$, serum creatinine $\left(\mathrm{Scr}_{72 \mathrm{~h}}\right)$, white blood cells $\left(\mathrm{WBC}_{72 \mathrm{~h}}\right)$, platelet $\left(\mathrm{PLT}_{72 \mathrm{~h}}\right)$, and hemoglobin and serum chloride at SICU admission $\left(\mathrm{Cl}_{0}\right)$. Systemic Inflammatory Response Syndrome (SIRS) score, Elixhauser comorbidity index, Sequential Organ Failure Assessment (SOFA) score, as well as Simplified Acute Physiology Score II (SAPS II), were acquired at $72 \mathrm{~h}$ after ICU admission. Moreover, survival data on the vital status was retrieved from the US Social Security death index records. In-hospital, thirty-day and ninety-day mortality constituted the endpoints for this analysis.

\section{Statistical analysis}

The sample was classified into two subgroups based on serum $\mathrm{Cl}^{-}$levels at $72 \mathrm{~h}$ after ICU admission: hyperchloremia $\left(\mathrm{Cl}_{72 \mathrm{~h}} \geq 108 \mathrm{mmol} / \mathrm{L}\right)$ and no hyperchloremia $(\mathrm{Cl}$ $72 \mathrm{~h}<108 \mathrm{mmol} / \mathrm{L}$ ). The baseline features of all the study subjects were stratified based on these two groups; with continuous variables indicated as mean \pm standard deviation (SD) or interquartile range (IQR) and median. Summaries of the categorical data are indicated as the percentage or number. The chi-squared test was employed to compare the categorical data. The Lowess smoothing method was employed to explore the association of serum $\mathrm{Cl}^{-}$with thirty-day mortality. To facilitate the clinical interpretation of our findings, we employed the Cox proportional hazards models to establish if serum $\mathrm{Cl}_{72 \mathrm{~h}}$ was independently linked to in-hospital, thirty-day and ninety-day mortality from all causes, with findings expressed as hazard ratios (HRs) with 95\% confidence intervals (CIs). We applied 2 multivariate models for all the endpoints. The no hyperchloremia group served as 
the control group. In model I, we adjusted covariates for age, ethnicity and male. In model II, we adjusted the covariates for age, ethnicity, male, SAPS II, renal replacement therapy (RRT), $\mathrm{Cl}_{0}, \mathrm{Scr}_{72 \mathrm{~h}}$, bicarbonate ${ }_{72 \mathrm{~h}}, \mathrm{PLT}_{72 \mathrm{~h}}$. These confounders were selected based on a change in effect estimate of more than $10 \%$.

Subgroup analyses were carried out to probe the interaction linking serum $\mathrm{Cl}{ }_{72} \mathrm{~h}$ with thirty-day all-cause mortality, consisting of coronary heart disease, hypertension, diabetes mellitus and acute kidney injury, Adjusted by age, ethnicity, male, SAPS II, RRT, $\mathrm{Cl}_{0}, \mathrm{Scr}_{72 \mathrm{~h}}$, bicarbonate $_{72 \mathrm{~h}}, \mathrm{PLT}_{72 \mathrm{~h}}$. The R software V.3.42 (The R Project for Statistical Computing, Vienna, Austria) was utilized for data analysis. $P$-value $<0.05$ represents statistical significance, with all reported $P$-values being two-sided.

\section{Results}

\section{Participant characteristics}

Overall, 2131 subjects were enrolled based on the inclusion criteria and were clustered into two groups. The study sample was divided into two subgroups according to the serum chloride levels at $72 \mathrm{~h}$ after ICU admission: $n=664$ subjects in the hypochloremia group and $n=1467$ subjects in the no hyperchloremia group (Fig. 1). The characteristics of the subjects based on serum
$\mathrm{Cl}^{-}$contents at $72 \mathrm{~h}$ after ICU admission are shown in Table 1. We observed that white male subjects exhibited a higher SICU hospitalization rate. Moreover, participants with hyperchloremia were more likely to be older, had higher SIRS, SOFA and SAPS II scores. Furthermore they also had higher admission serum chloride, sodium and sodium at $72 \mathrm{~h}$ after admission to ICU, longer length of ICU stay and hospital stay.

\section{Chloride levels and clinical endpoints}

Figure 2 indicates that $\mathrm{Cl}_{72 \mathrm{~h}}$ was non-linearly linked to the thirty-day mortality from all causes. A J-shaped association was reported, demonstrating that hyperchloremia was associated with an elevated risk of thirty-day mortality from all causes. Multivariate analysis adjusted for age, male, and ethnicity demonstrated that hyperchloremia were good predictors of risk for in-hospital, thirty-day and ninety-day mortality from all causes, with adjusted HRs (95\% CIs) for hyperchloremia being 1.32 (1.04 1.69), 1.68 (1.32 2.12), and 1.51 (1.24 1.83), respectively. After adjusting for age, ethnicity, male, SAPS II, RRT, $\mathrm{Cl}_{0}, \mathrm{Scr}_{72 \mathrm{~h}}$, bicarbonate ${ }_{72 h}, \mathrm{PLT}_{72 \mathrm{~h}}$, we established that hyperchloremia was still a reliable risk predictor for in-hospital, thirty-day and ninety-day mortality from all causes, and adjusted HRs (95\% CIs) for

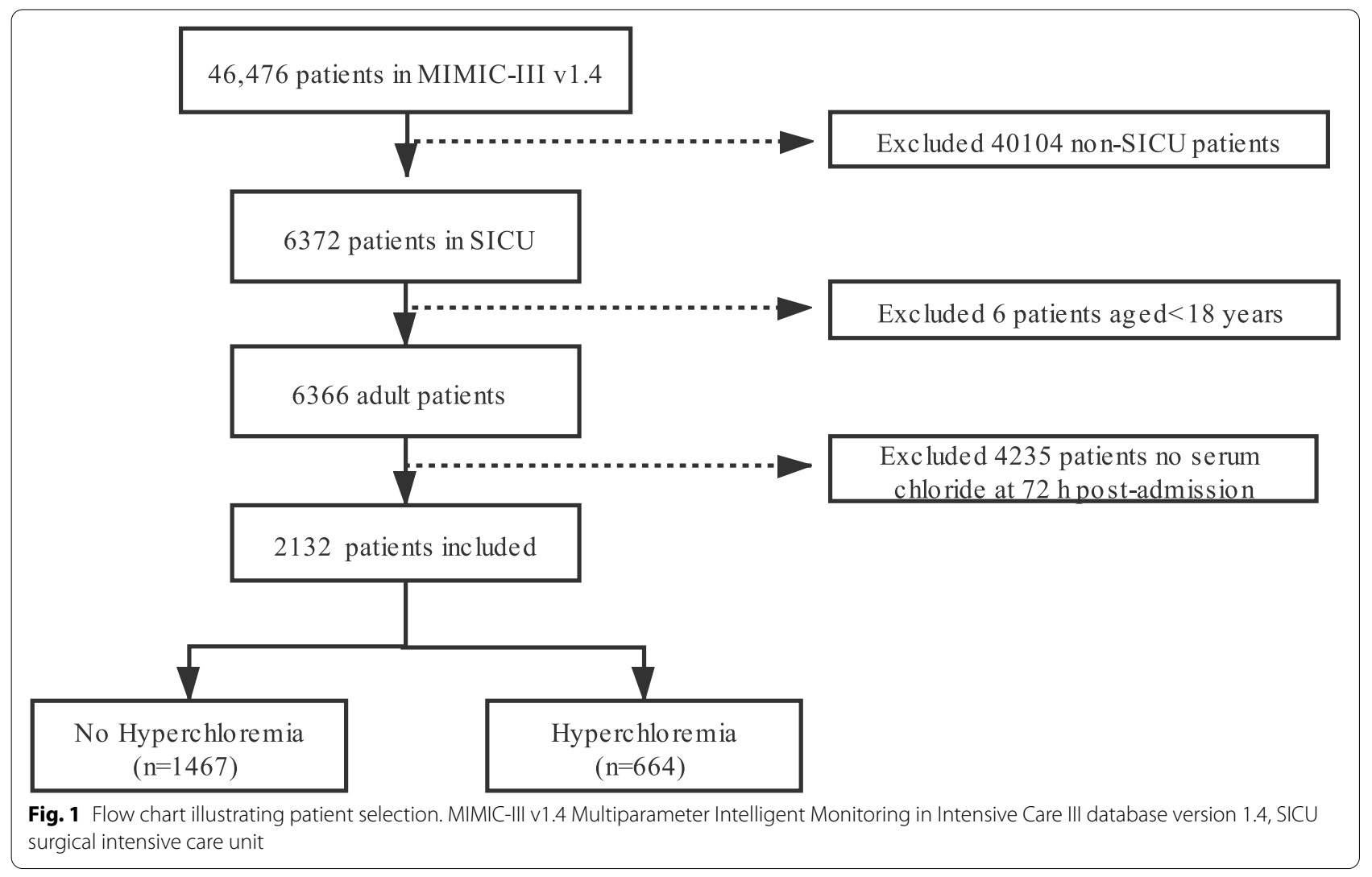


Table 1 Clinical Features Stratified by Serum Chloride at $72 \mathrm{~h}$ post-ICU admission

\begin{tabular}{|c|c|c|c|c|}
\hline Variable & Total $(n=2131)$ & $\begin{array}{l}\text { No Hyperchloremia } \\
\left(\mathrm{Cl}_{72 \mathrm{~h}}<108, n=1467\right)\end{array}$ & $\begin{array}{l}\text { Hyperchloremia } \\
\left(\mathrm{Cl}_{72 \mathrm{~h}} \geq 108, n=664\right)\end{array}$ & $P$-value \\
\hline Age, yr, median (IQR) & $64.0(52.0-77.0)$ & $63.0(52.0-76.0)$ & $67.0(53.0-78.2)$ & $<0.001$ \\
\hline Male, n(\%) & $1110(52.1 \%)$ & $787(53.6 \%)$ & $323(48.6 \%)$ & 0.032 \\
\hline \multicolumn{4}{|l|}{ Ethnicity, n(\%) } & \multirow[t]{5}{*}{$<0.001$} \\
\hline White & $1565(73.4 \%)$ & $1114(75.9 \%)$ & $451(67.9 \%)$ & \\
\hline Black & $182(8.5 \%)$ & $120(8.2 \%)$ & $62(9.3 \%)$ & \\
\hline Asian & $73(3.4 \%)$ & $46(3.1 \%)$ & $27(4.1 \%)$ & \\
\hline Other & $311(14.6 \%)$ & $187(12.7 \%)$ & $124(18.7 \%)$ & \\
\hline \multicolumn{5}{|l|}{ Comorbidities, n (\%) } \\
\hline Coronary heart disease & $246(11.5 \%)$ & $170(11.6 \%)$ & $76(11.4 \%)$ & 0.924 \\
\hline COPD & $29(1.4 \%)$ & $22(1.5 \%)$ & $7(1.1 \%)$ & 0.411 \\
\hline Hypertension & $982(46.1 \%)$ & $669(45.6 \%)$ & $313(47.1 \%)$ & 0.51 \\
\hline Diabetes mellitus & $544(25.5 \%)$ & $383(26.1 \%)$ & $161(24.2 \%)$ & 0.362 \\
\hline Acute kidney injury & $508(23.8 \%)$ & $343(23.4 \%)$ & $165(24.8 \%)$ & 0.461 \\
\hline \multicolumn{5}{|l|}{ Scoring systems, median (IQR) } \\
\hline SIRS & $3.0(2.0-4.0)$ & $3.0(2.0-4.0)$ & $3.0(2.0-4.0)$ & 0.005 \\
\hline SOFA & $4.0(2.0-6.0)$ & $3.0(2.0-6.0)$ & $4.0(2.0-6.0)$ & $<0.001$ \\
\hline SAPSII & $35.0(26.0-44.0)$ & $33.0(25.0-43.0)$ & $37.0(29.0-47.0)$ & $<0.001$ \\
\hline Elixhauser comorbidity & $11.0(1.0-20.0)$ & $11.0(0.0-20.0)$ & $11.0(3.0-20.0)$ & 0.06 \\
\hline \multicolumn{5}{|l|}{ Therapeutic exposure in ICU,n(\%) } \\
\hline Renal replacement therapy & $90(4.2 \%)$ & $77(5.2 \%)$ & $13(2.0 \%)$ & $<0.001$ \\
\hline Diuretic & 1052 (49.4\%) & $708(48.3 \%)$ & $344(51.8 \%)$ & 0.129 \\
\hline Statin & $684(32.1 \%)$ & $459(31.3 \%)$ & $225(33.9 \%)$ & 0.234 \\
\hline Pressin & $161(7.6 \%)$ & $99(6.7 \%)$ & $62(9.3 \%)$ & 0.036 \\
\hline Plasmalyte & $6(0.3 \%)$ & $4(0.3 \%)$ & $2(0.3 \%)$ & 0.908 \\
\hline \multicolumn{2}{|c|}{$\begin{array}{l}\text { Fluid balance within } 72 \mathrm{~h} \text { after ICU admission(mL), }-2176.0 \text { (- 6688.0- 3296.0) } \\
\text { median (IQR) }\end{array}$} & $-1977.0(-6284.0,2945.0)$ & $-2980.0(-7464.0,4446.0)$ & 0.203 \\
\hline \multicolumn{2}{|c|}{ Admission serum bicarbonate(mmol/L), median (IQR) 24.0 (21.0-26.0) } & $24.0(22.0-27.0)$ & $23.0(20.0-25.0)$ & $<0.001$ \\
\hline \multicolumn{2}{|c|}{$\begin{array}{l}\text { Serum bicarbonate at } 72 \mathrm{~h} \text { after ICU } 25.0 \text { (23.0-28.0) } \\
\operatorname{admission}(\mathrm{mmol} / \mathrm{L}) \text {, median (IQR) }\end{array}$} & $26.0(24.0-28.0)$ & $23.0(20.0-25.0)$ & $<0.001$ \\
\hline Admission serum $\mathrm{Cl}^{-}(\mathrm{mmol} / \mathrm{L})$, median (IQR) & $105.0(101.0-108.0)$ & $104.0(101.0-107.0)$ & $107.5(104.0-111.0)$ & $<0.001$ \\
\hline Admission serum sodium (mmol/L), median (IQR) & $139.0(136.0-141.0)$ & $138.0(135.0-140.0)$ & $140.0(138.0-142.0)$ & $<0.001$ \\
\hline $\begin{array}{l}\text { Serum sodium at } 72 \mathrm{~h} \text { after ICU admission(mmol/L), } \\
\text { median (IQR) }\end{array}$ & $139.0(137.0-142.0)$ & $138.0(136.0-140.0)$ & $143.0(141.0-146.0)$ & $<0.001$ \\
\hline Length of ICU stay, d, median (IQR) & $5.0(2.0-9.0)$ & $4.0(2.0-8.0)$ & $7.0(4.0-13.0)$ & $<0.001$ \\
\hline Length of hospital stay, d, median (IQR) & $12.0(8.0-19.0)$ & $11.0(7.0-18.0)$ & $14.0(8.0-22.0)$ & $<0.001$ \\
\hline
\end{tabular}

ICU intensive care unit, IQR interquartile range, COPD chronic obstructive pulmonary disease, SIRS Systemic Inflammatory Response Syndrome, SOFA Sequential Organ Failure Assessment, SAPS I/ Simplified Acute Physiology Score II

hyperchloremia were 1.35 (1.02 1.77), 1.67 (1.28 2.19), and $1.39(1.12 \sim 1.73)$, respectively (Table 2$)$.

The Kaplan-Meier curve of thirty-day mortality based on serum $\mathrm{Cl}^{-}$at $72 \mathrm{~h}$ post-ICU admission is shown in Fig. 3. Cumulative thirty-day survival rates at $72 \mathrm{~h}$ postICU admission were 84.97 and $86.01 \%$ in the hyperchloremia and no hyperchloremia groups, respectively $(P=0.0011)$. Meanwhile, cumulative ninety-day survival rates at $72 \mathrm{~h}$ post-ICU admission were 93.01 and $93.80 \%$ in the hyperchloremia and no hyperchloremia groups, respectively $(P=0.0098)$ (Fig. 3$)$.

\section{Subgroup analyses}

Subgroup analyses were carried out to investigate the relationship of serum $\mathrm{Cl}^{-}$at $72 \mathrm{~h}$ post-ICU admission with the thirty-day mortality from all causes. There were no notable interactions with coronary heart disease, hypertension, and diabetes mellitus ( $\mathrm{P}$ for interaction: 0.418, 0.157, 0.103, respectively). But the hyperchloremia had an interactions with AKI, the no AKI patient who had hyperchloremia would have a higher thirty-day mortality( $\mathrm{P}$ for interaction: 0.017) (Table 3). 


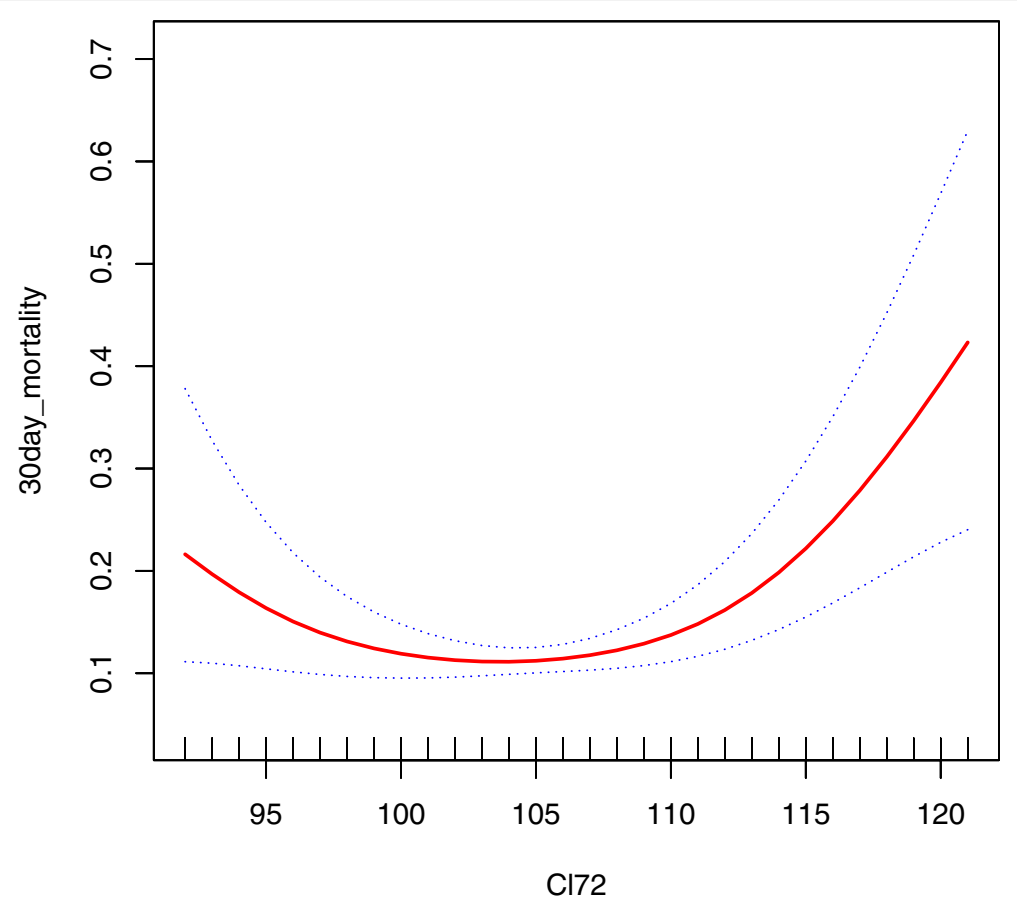

Fig. 2 Relationship between serum chloride at $72 \mathrm{~h}$ after ICU admission and 30-day all-cause mortality. $\mathrm{Cl}_{72}$ serum chloride at $72 \mathrm{~h}$ after ICU admission

Table 2 Hazard ratios and 95\% confidence intervals for mortality across groups of serum chloride at $72 \mathrm{~h}$ after ICU admission

\begin{tabular}{|c|c|c|c|c|c|c|}
\hline \multirow[t]{2}{*}{ Chloride } & \multicolumn{2}{|l|}{ Non-adjusted } & \multicolumn{2}{|l|}{ Model I } & \multicolumn{2}{|l|}{ Model II } \\
\hline & $\mathrm{HR}(95 \% \mathrm{CI})$ & $P$-value & $\mathrm{HR}(95 \% \mathrm{CI})$ & $P$-value & $\mathrm{HR}(95 \% \mathrm{Cl})$ & $P$-value \\
\hline \multicolumn{7}{|c|}{ Hospital all-cause mortality } \\
\hline \multicolumn{7}{|c|}{ fitted groups, mmol/L } \\
\hline$<108$ & 1.0 (ref) & & 1.0 (ref) & & 1.0 (ref) & \\
\hline$\geq 108$ & $1.47(1.15,1.87)$ & 0.002 & $1.32(1.04 \sim 1.69)$ & 0.025 & $1.35(1.02 \sim 1.77)$ & 0.035 \\
\hline \multicolumn{7}{|c|}{ 30-day all-cause mortality } \\
\hline \multicolumn{7}{|c|}{ fitted groups, mmol/L } \\
\hline$<108$ & 1.0 (ref) & & 1.0 (ref) & & 1.0 (ref) & \\
\hline$\geq 108$ & $1.86(1.47,2.35)$ & $<0.001$ & $1.68(1.32 \sim 2.12)$ & $<0.001$ & $1.67(1.28 \sim 2.19)$ & $<0.001$ \\
\hline \multicolumn{7}{|c|}{ 90-day all-cause mortality } \\
\hline \multicolumn{7}{|c|}{ fitted groups, mmol/L } \\
\hline$<108$ & 1.0 (ref) & & 1.0 (ref) & & $1.0($ ref) & \\
\hline$\geq 108$ & $1.64(1.35,1.98)$ & $<0.001$ & $1.51(1.24 \sim 1.83)$ & $<0.001$ & $1.39(1.12 \sim 1.73)$ & 0.003 \\
\hline
\end{tabular}

Models were derived using Cox proportional hazards regression models

Non-adjusted model adjusted for: none

Adjust I model adjust for: age, ethnicity, male

Adjust II model adjust for: age, ethnicity, male, SAPS II, RRT, $\mathrm{Cl}_{0}, \mathrm{Scr}_{72 \mathrm{~h}}$, bicarbonate ${ }_{72} \mathrm{~h}, \mathrm{PLT}_{72 \mathrm{~h}}$

$H R$ hazard ratio, $\mathrm{Cl}$ confidence interval, SAPS /I Simplified Acute Physiology Score II, RRT renal replacement therapy, $\mathrm{Cl}_{0}$ admission serum chloride, $\mathrm{Scr}_{72 \mathrm{~h}} \mathrm{Creatinine}_{72 \mathrm{~h}}$ $P L T_{72 h}$ platelet $_{72 \mathrm{~h}}$

\section{Discussion}

Herein, we reported a J-shaped association linking serum chloride levels at $72 \mathrm{~h}$ post-ICU admission to thirty-day mortality from all causes. After multivariate logistic regression assessment was adjusted for other significant variables, we found that hyperchloremia remained 
30day_mortality

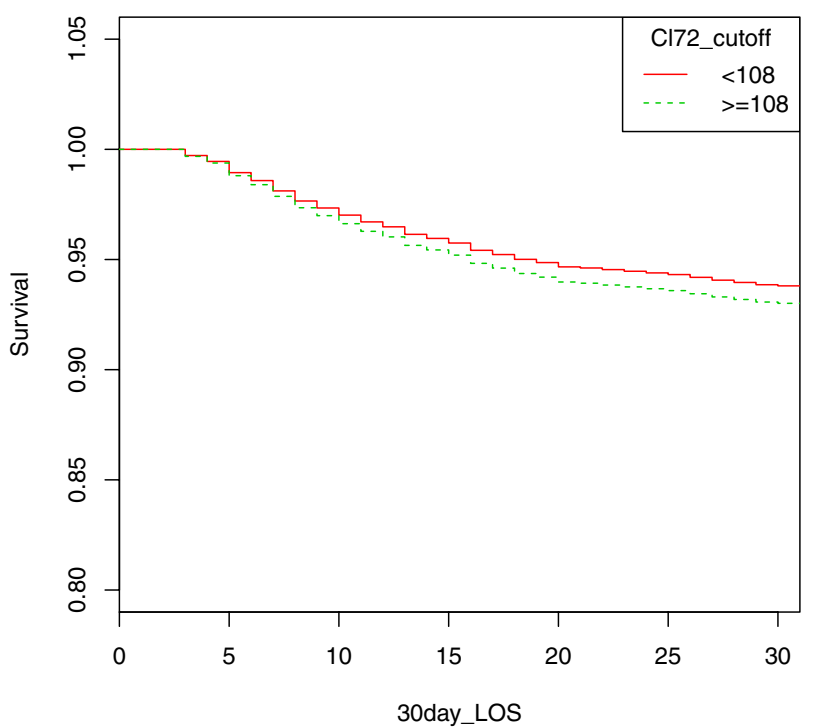

90day_mortality

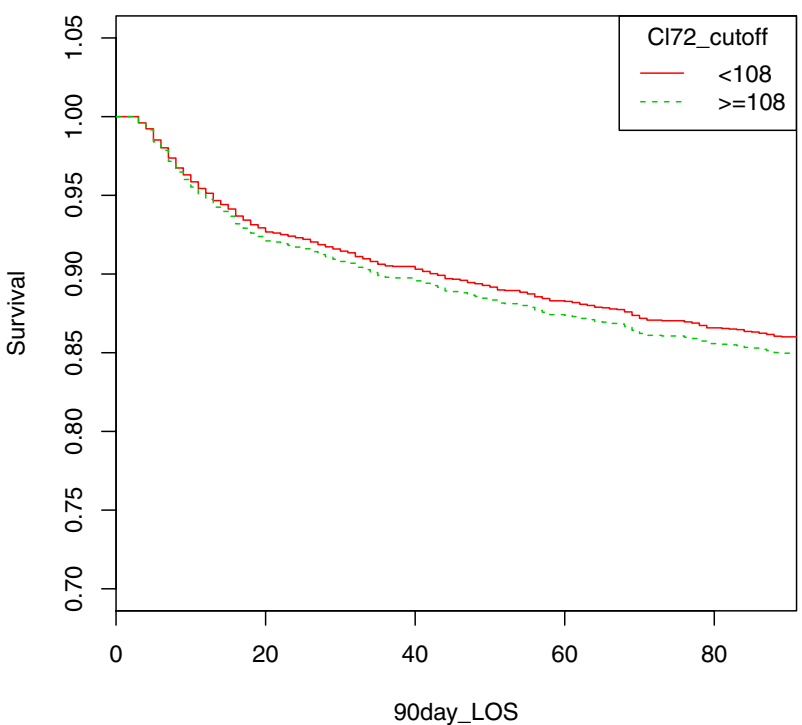

Fig. 3 Kaplan-Meier curve of 30-day and 90-day mortality serum chloride at $72 \mathrm{~h}$ after ICU admission. ICU intensive care unit, $\mathrm{Cl}_{72}$ serum chloride at $72 \mathrm{~h}$ after ICU admission, LOS long of survival

Table 3 Subgroup Analysis of the Comorbidities between serum Chloride at $72 \mathrm{~h}$ after ICU Admission and 30 day All-cause Mortality

\begin{tabular}{|c|c|c|c|c|c|}
\hline & $\mathrm{N}$ & $\begin{array}{l}\text { No Hyperchloremia } \\
\left(\mathrm{Cl}_{72 \mathrm{~h}}<108\right) \\
\mathrm{HR}(95 \% \mathrm{Cl})\end{array}$ & $\begin{array}{l}\text { Hyperchloremia } \\
\left(\mathrm{Cl}_{72 \mathrm{~h}} \geq 108\right) \\
\mathrm{HR}(95 \% \mathrm{Cl})\end{array}$ & $P$ value & P for interaction \\
\hline Coronary heart disease & & & & & 0.418 \\
\hline No & 1885 & 1.0 (ref) & $1.69(1.26 \sim 2.25)$ & $<0.001$ & \\
\hline Yes & 246 & 1.0 (ref) & $2.17(1.05 \sim 4.51)$ & 0.037 & \\
\hline Hypertension & & & & & 0.157 \\
\hline No & 1149 & 1.0 (ref) & $1.3(0.89 \sim 1.9)$ & 0.169 & \\
\hline Yes & 982 & 1.0 (ref) & $2.36(1.61 \sim 3.48)$ & $<0.001$ & \\
\hline Diabetes mellitus & & & & & 0.103 \\
\hline No & 1587 & 1.0 (ref) & $1.93(1.43 \sim 2.62)$ & $<0.001$ & \\
\hline Yes & 544 & 1.0 (ref) & $1.25(0.69 \sim 2.27)$ & 0.465 & \\
\hline Acute kidney injury & & & & & 0.017 \\
\hline No & 1623 & 1.0 (ref) & $2.22(1.57 \sim 3.14)$ & $<0.001$ & \\
\hline Yes & 508 & 1.0 (ref) & $1.06(0.68 \sim 1.66)$ & 0.794 & \\
\hline
\end{tabular}

ICU intensive care unit, $\mathrm{Cl}_{72}$ serum chloride at $72 \mathrm{~h}$ after ICU admission

independently associated with in-hospital, thirty-day and ninety-day mortality from all causes in patients admitted to the SICU.

Our study contributes to the growing research evidence indicating that hyperchloremia might be harmful in specific inpatient populations. Similarly, a previous investigation reported hyperchloraemia at $48 \mathrm{~h}$ was markedly linked to AKI and mortality in a multidisciplinary intensive care unit [5]. Moreover, hyperchloremia $48 \mathrm{~h}$ post-admission along with $\Delta \mathrm{Cl}^{-}$(the delta of chloride between the ICU admission and $48 \mathrm{~h}$ ) were related to thirty-day mortality in major trauma patients [8]. More and more studies have shown that hyperchloremia is linked to mortality after surgery $[9,10,13,14]$, with the possible cause being fluid replacement during surgery which often consists of serum with high chlorine content. Moreover, after admission to the ICU, the possible cause of hyperchloraemia is intravenous infusion 
[15]. The most commonly used liquid for hospitalization is normal saline, and the average $\mathrm{Cl}^{-}$concentration is $154 \mathrm{Eq} / \mathrm{L}$, which is higher than the average normal plasma $\mathrm{Cl}^{-}$concentration [16]. At the same time, normal saline is often used as a diluent for drugs and might be an unaccounted source of chloride in the ICU. A large sample-sized retrospective investigation from a singlecenter ICU showed that maintenance and replacement fluids markedly contributed to daily $\mathrm{Cl}^{-}$intake relative to resuscitation fluids [17]. Hyperchloremia can be toxic to cells, causing unwarranted requirements on cellular energy metabolism [18], and contributes to additional morbidity and mortality [19]. Hence, caution should be taken to minimize serum chlorine overload [20].

Taken together, our study found that serum $\mathrm{Cl}^{-}$content at $72 \mathrm{~h}$ post-admission was associated with mortality from all causes in severely ill patients admitted to the surgical intensive care unit. To our knowledge, this is the first study in a broad SICU population. The strengths of this study include its large sample size and the multivariate adjustment for clinical confounders directly related to hyperchloremia and hospital mortality, including SOFA, SAPS II score, SIRS, and AKI. No previous study has documented the relationship of serum $\mathrm{Cl}^{-}$level with hospital mortality while also accounting for confounding factors. The multivariate design, along with the patient population, The multivariate design, along with the patient population contributed to the robustness of this study.

\section{Conclusion}

We found that hyperchloremia at $72 \mathrm{~h}$ post-ICU admission and increasing serum chloride were associated with an elevated risk of mortality from all causes in critically ill SICU patients. However, further in-depth studies in larger prospective multi-centers are warranted to verify and substantiate our findings.

\section{Limitation}

Nevertheless, our present study has several limitations. Firstly, this study is a single-center retrospective study that possesses inherent biases. Secondly, we collected data for serum $\mathrm{Cl}$ - in patients at $72 \mathrm{~h}$ post-ICU admission only and did not assess other time points during the SICU stay. Finally, although we applied a multivariate model to control bias, many other known and unknown factors remain.

\footnotetext{
Abbreviations

SICU: Surgical intensive care unit; MIMIC-III v1.4: Multiparameter Intelligent Monitoring in Intensive Care III database version 1.4; ICU: Intensive care unit; $\mathrm{Cl}^{-}$: Chloride; Na: Sodium; K: Potassium; BUN: Blood urea nitrogen; Scr: Serum creatinine; WBC: White blood cells; SIRS: Systemic Inflammatory Response Syndrome; SOFA: Sequential Organ Failure Assessment; SAPS II: Simplified Acute Physiology Score II; AKI: Acute kidney injury.
}

\section{Acknowledgments \\ None.}

\section{Authors' contributions}

Keke Song helped with the conception and design of the project, the acquisition and interpretation of data, the drafting and revision of the manuscript. Tingting Yang helped with the acquisition and interpretation of data and contributed to critical content revision. Wei Gao contributed to the critical revision of the manuscript. The authors read and approved the final manuscript.

\section{Funding}

This study was supported by The National Natural Science Foundation of China (NO.81771485).

\section{Availability of data and materials}

The datasets used and/or analyzed during the current study will be available from the corresponding author on reasonable request. However, reanalysis of the full data needs to be approved by the MIMIC III Institute.

\section{Declarations}

\section{Ethics approval and consent to participate}

MIMIC-III v1.4 is publicly available to researchers who have completed a 'protecting human subjects' training. Data presented in this study were extracted by Song, who completed the online training course of the National Institutes of Health (certification number: 37814178). The authors confirm that all methods were performed in accordance with the relevant guidelines and regulations in the methods section.

\section{Consent for publication}

Not applicable.

\section{Competing interests}

The authors declare that they have no competing interests.

Received: 25 March 2021 Accepted: 29 December 2021

Published online: 07 January 2022

\section{References}

1. Berend K, Van Hulsteijn LH, Gans RO. Chloride: the queen of electrolytes? Eur J Intern Med. 2012;23(3):203-11.

2. Yunos NM, Bellomo R, Story D, et al. Bench-to-bedside review: chloride in critical illness. Crit Care. 2010;14(4):226.

3. Sumarsono A, Wang J, Xie L, et al. Prognostic value of Hypochloremia in critically ill patients with decompensated cirrhosis. Crit Care Med. 2020;48(11):e1054-61.

4. Zhang Y, Peng R, Li X, et al. Serum chloride as a novel marker for adding prognostic information of mortality in chronic heart failure. Clin Chim Acta. 2018;483:112-8.

5. De Vasconcellos K, Skinner DL. Hyperchloraemia is associated with acute kidney injury and mortality in the critically ill: a retrospective observational study in a multidisciplinary intensive care unit. J Crit Care. 2018;45:45-51.

6. Ferreira JP, Girerd N, Duarte K, et al. Serum chloride and sodium interplay in patients with acute myocardial infarction and heart failure with reduced ejection fraction: an analysis from the high-risk myocardial infarction database initiative. Circ Heart Fail. 2017;10(2):e003500.

7. Kubota K, Sakaguchi Y, Hamano T, et al. Prognostic value of hypochloremia versus hyponatremia among patients with chronic kidney diseasea retrospective cohort study. Nephrol Dial Transplant. 2020;35(6):987-94.

8. Lee JY, Hong TH, Lee KW, et al. Hyperchloremia is associated with 30-day mortality in major trauma patients: a retrospective observational study. Scand J Trauma Resusc Emerg Med. 2016;24(1):117.

9. Neyra JA, Canepa-Escaro F, Li X, et al. Association of Hyperchloremia with Hospital Mortality in critically ill septic patients. Crit Care Med. 2015:43(9):1938-44.

10. Mccluskey SA, Karkouti K, Wijeysundera D, et al. Hyperchloremia after noncardiac surgery is independently associated with increased morbidity 
and mortality: a propensity-matched cohort study. Anesth Analg. 2013;117(2):412-21.

11. Barhight MF, Brinton J, Stidham T, et al. Increase in chloride from baseline is independently associated with mortality in critically ill children. Intensive Care Med. 2018:44(12):2183-91.

12. Johnson AE, Pollard TJ, Shen L, et al. MIMIC-III, a freely accessible critical care database. Sci Data. 2016;3:160035.

13. Lombardi G, Ferraro PM, Bargagli M, et al. Hyperchloremia and acute kidney injury: a retrospective observational cohort study on a general mixed medical-surgical not ICU-hospitalized population. Intern Emerg Med. 2020;15(2):273-80

14. Oh TK, Do SH, Jeon YT, et al. Association of Preoperative Serum Chloride Levels with Mortality and Morbidity after Noncardiac Surgery: a retrospective cohort study. Anesth Analg. 2019;129(6):1494-501.

15. Pfortmueller CA, Uehlinger $D$, Von Haehling $S$, et al. Serum chloride levels in critical illness-the hidden story. Intensive Care Med Exp. 2018;6(1):10.

16. Williams EL, Hildebrand KL, Mccormick SA, et al. The effect of intravenous lactated Ringer's solution versus $0.9 \%$ sodium chloride solution on serum osmolality in human volunteers. Anesth Analg. 1999;88(5):999-1003.

17. Van Regenmortel N, Verbrugghe W, Roelant $\mathrm{E}$, et al. Maintenance fluid therapy and fluid creep impose more significant fluid, sodium, and chloride burdens than resuscitation fluids in critically ill patients: a retrospective study in a tertiary mixed ICU population. Intensive Care Med. 2018:44(4):409-17.

18. Veech RL. The toxic impact of parenteral solutions on the metabolism of cells: a hypothesis for physiological parenteral therapy. Am J Clin Nutr. 1986:44(4):519-51.

19. Lobo DN, Awad S. Should chloride-rich crystalloids remain the mainstay of fluid resuscitation to prevent 'pre-renal' acute kidney injury?: con. Kidney Int. 2014;86(6):1086-105.

20. Rein JL, Coca SG. "I don't get no respect": the role of chloride in acute kidney injury. Am J Physiol Renal Physiol. 2019;316(3):F587-f605.

\section{Publisher's Note}

Springer Nature remains neutral with regard to jurisdictional claims in published maps and institutional affiliations.

Ready to submit your research? Choose BMC and benefit from:

- fast, convenient online submission

- thorough peer review by experienced researchers in your field

- rapid publication on acceptance

- support for research data, including large and complex data types

- gold Open Access which fosters wider collaboration and increased citations

- maximum visibility for your research: over $100 \mathrm{M}$ website views per year

At BMC, research is always in progress.

Learn more biomedcentral.com/submissions 